\title{
Teacher Educator Identity in a Culture of Iterative Teacher Education Program Design: A Collaborative Self-Study
}

\author{
Aurora Chang \\ Loyola University Chicago, achang2@luc.edu \\ Sabina Rak Neugebauer \\ Loyola University Chicago, sabina.neugebauer@temple.edu \\ Aimee Papola-Ellis \\ Loyola University Chicago, apapola@luc.edu \\ David Ensminger \\ Loyola University Chicago, densmin@luc.edu

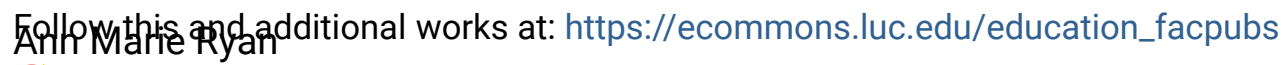

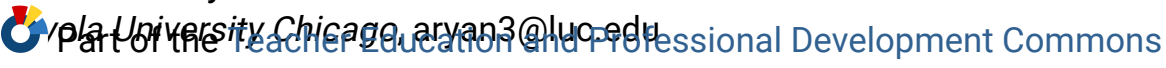 \\ Author Manuscript

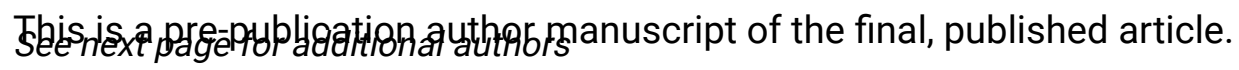

\section{Recommended Citation}

Chang, Aurora; Neugebauer, Sabina Rak; Papola-Ellis, Aimee; Ensminger, David; Ryan, Ann Marie; and Kennedy, Adam. Teacher Educator Identity in a Culture of Iterative Teacher Education Program Design: A Collaborative Self-Study. Studying Teacher Education, 12, 2: 152-169, 2016. Retrieved from Loyola eCommons, Education: School of Education Faculty Publications and Other Works, http://dx.doi.org/ $10.1080 / 17425964.2016 .1192030$

This Article is brought to you for free and open access by the Faculty Publications and Other Works by Department at Loyola eCommons. It has been accepted for inclusion in Education: School of Education Faculty Publications and Other Works by an authorized administrator of Loyola eCommons. For more information, please contact ecommons@luc.edu.

\section{(c) $(1) \ominus$}

This work is licensed under a Creative Commons Attribution-Noncommercial-No Derivative Works 3.0 License.

(c) Taylor \& Francis 2016. 


\section{Authors}

Aurora Chang, Sabina Rak Neugebauer, Aimee Papola-Ellis, David Ensminger, Ann Marie Ryan, and Adam Kennedy 


\title{
Teacher Educators' Experiences around Teacher Education Redesign: A Collaborative Self-Study
}

\author{
Aurora Chang, Ph.D. \\ Assistant Professor, Teaching and Learning \\ Loyola University Chicago \\ 820 N. Michigan Avenue \\ Lewis Towers, 10th Floor \\ achang2@luc.edu \\ Sabina Rak Neugebauer \\ Assistant Professor, Teaching and Learning \\ Loyola University Chicago \\ 820 N. Michigan Avenue \\ Lewis Towers, 10th Floor \\ Chicago, IL 60611 \\ sneugebauer@luc.edu
}

Aimee Ellis
Assistant Professor, Teaching and Learning
Loyola University Chicago
820 N. Michigan Avenue
Lewis Towers, 10th Floor
Chicago, IL 60611
apapola@luc.edu
David Ensminger
Assistant Professor, Teaching and Learning
Loyola University Chicago
820 N. Michigan Avenue
Lewis Towers, 11th Floor
Chicago, IL 60611
Densmin@luc.edu

Ann Marie Ryan

Associate Dean of Academic Programs \& Associate Professor, Teaching and Learning

Loyola University Chicago

820 N. Michigan Avenue

Lewis Towers, 10th Floor 
Chicago, IL 60611

Aryan@luc.edu

Adam Kennedy

Assistant Professor, Teaching and Learning

Loyola University Chicago

820 N. Michigan Avenue

Lewis Towers, 11th Floor

Chicago, IL 60611

Akenne5@luc.edu 


\title{
Teacher Educator Identity in a Culture of Iterative Teacher Education Program Design: A Collaborative Self-Study
}

\begin{abstract}
Faculty in the School of Education at our institution have collaborated to re-envision teacher education at our university. A complex, dynamic, time-consuming and sometimes painstaking process, redesigning a teacher education program from a traditional approach (i.e., where courses focus primarily on theoretical principles of practice through textbooks and University-based classroom discussions), to a model of teacher education that embraces teaching, learning and leading with schools and in communities is challenging, yet exciting work. Little is known about teacher educators' experiences as they either design or deliver collaborative field-based models of teacher education. In this article, we examine our experiences in the second implementation year of our redesigned teacher education program, Teaching, Learning, and Leading with Schools and Communities (TLLSC) and how these unique experiences inform our teacher educator identities. Through a collaborative self-study, we sought to make meaning of our transformation from a faculty delivering a traditional model to educators collectively implementing a field-based model, by analyzing the diverse perspectives of faculty at different entry points in the TLLSC development and implementation process. We found that our participation in an intensive field-based teacher preparation model challenged our notions of teacher educator identity. In a culture of iterative program design this study documents the personal and professional shifts in identity required to accomplish this collaborative and dynamic change in approach to teacher education.
\end{abstract}


TEACHER EDUCATION REDESIGN: A COLLABORATIVE SELF-STUDY

\section{Teacher Educator Identity in a Culture of Iterative Teacher Education Program Design: A Collaborative Self-Study}

Recent calls for improving the preparation of teachers have touted the advantages of field-based approaches to teacher education (Ball \& Forzani, 2009; Labaree, 2010; Ryan, Ensminger, Heineke, Kennedy, Kennedy, Prasse \& Smetana, 2014). Field-based programs place primary emphasis on embedded experiences in educational settings for teacher candidates; such programs depend on strong, continuously evolving universityschool partnerships. Field-based experiences for teacher candidates can better ensure teacher candidates have preservice experiences that make them profession-ready from the very start of their teaching career, and, equally important, these models have been found to be more effective in increasing student outcomes (Boyd, Grossman, Lankford, Loeb, \& Wyckoff, 2008). Teacher preparation programs that adopt these models are commonly evaluated based on teacher candidates’ amount of actual time spent in classrooms (Ryan et al., 2014).

Yet, simply increasing the number of hours preservice teachers spend in the field is insufficient for increasing the efficacy of future teachers. According to DarlingHammond (2006), these types of experiences should be “...extensive and intensely supervised...tightly integrated with coursework...that allows candidates to learn from expert practice in schools that serve diverse students” (p. 307). Indeed, research indicates that teacher preparation programs better prepare teachers in training when they align their curriculum to field-based experiences and generate mutually beneficial collaborations with local school partners, as well as provide wide-ranging opportunities for field-based experiences in local schools, (Boyd et al., 2008). In line with these findings the former 
National Council for Accreditation of Teacher Education’s Blue Ribbon Panel report called for a re-envisioning of teacher education to put more emphasis on these extensive field-based experiences, which require more of an apprenticeship relationship between teacher candidate and practicing teacher (McDonald, Kazemi, \& Kavanagh, 2013).

However, the kind of apprenticing--where students are immersed in the intricacies of effective teaching practice through intense, long-term, rich relationships with classroom activity--necessary to support this model requires that faculty change from the traditional manner in which they were trained. This traditional training typically includes compartmentalized programs, where university professors teach their students the theoretical principles of practice through textbooks and university-based classroom discussions, which are then followed by piecemeal field-based experiences that are relatively brief and often dictated by university scheduling (Ryan et al., 2014). In addition to the sometimes lofty theoretical principles and limited field based experiences, Lortie (1975) notes that many aspiring teacher candidates learn about teaching through a sort of passive imagining of what it might be like to teach. In other words, their assumptions about teaching are based solely on what they have observed as successful students themselves (i.e. the apprenticeship-of-observation), not realizing the complexity involved behind the scenes in effectively teaching. As Lortie (1975) notes, "the apprenticeship-ofobservation [model] is not likely to instill a sense of the problematics of teaching - that students, because of the limits of their vantage point and empathetic capacity, will see it simplistically” (p. 65). In apprenticeship models, roles for practicing teachers and teacher candidates may be more easily conceptualized than those of teacher educators. Preparing undergraduate teacher candidates in PK-12 classrooms over four years may 
TEACHER EDUCATION REDESIGN: A COLLABORATIVE SELF-STUDY

necessitate significant role and identity shifts for teacher educators; however, the nature, mechanisms, and supports for those shifts are largely unexplored.

Thus, the focus of this article is on teacher educators' professional identities; specifically, shifts in professional identity in the context of a transition from universitybased to field-based teacher field-based teacher education. Teachers’ professional identities are socially situated and legitimated (Coldron \& Smith, 1999); that is, teachers’ professional development is not solely composed of their growing knowledge base and skill, but also includes their ability to define themselves and have others see them as teachers (Simon \& Johnson, 2015). Biographical studies tracking teachers’ careers over time indicate that the conception of the self is a "complex, multidimensional and dynamic system of representations and meanings which develops over time as the result of interactions between the person and an environment” (Kelchtermans \& Vandenberghe, 1994, p. 47). This understanding of professional identity, as that which can be redefined based on one’s changing context (MacLure, 1993), makes an investigation of how teacher educators’ professional identities shift to accommodate field-based experiences informative for the profession. Previous studies on professional teacher identities have demonstrated the deleterious effects of shifts in models and policies on teacher professional identities (Hong, 2010; Weiner \& Torres, 2016) with ramifications for their understanding of their developing teacher identity and sense of self. In the present investigation, we will present a description of the context for these professional identity shifts (including specific programmatic changes associated with a shift into field-based teacher education), after which we capture some of the ways in which faculty members' professional identities were both defined and redefined within this context. 


\section{Literature Review}

Teacher education has endured increasingly heavy scrutiny for decades, as stakeholders continue to demand accountability and change in public schools that "fail" our children. This focus on teacher education is a global matter (Conroy, Hulme, \& Menter, 2013; Hökkä \& Eteläpelto, 2014; Murray, 2008), and the reform of teacher education programs does not come without challenges, including a sense of global competition for today’s young students (Hökkä \& Eteläpelto, 2014), as well as top-down policies and mandates that impact classroom teachers, making it challenging to find local contexts in which teacher candidates can learn to apply best instructional practices (Sterrett \& Bond, 2012). Today’s teacher candidates must be equipped to “...understand and respond to the dense and multifaceted nature of the classroom...” (DarlingHammond, 2006, p. 305). For decades, society has linked almost every social problem in the United States to an educational problem, blaming teachers and those preparing teachers (Bullough, 2014; Forzani, 2014). However, by blaming teachers, critics also opened the door to change - empowering teachers to become social justice agents with the potential for lasting and significant impact through their daily decision-making in the classroom (Cochran-Smith \& Lytle, 1999).

Teacher education programs have responded to this blaming in various ways. Some have reassessed and revamped their programs altogether; others have made incremental changes appropriate to their contexts; still others have remained the same. However, the critique of university-based teacher education programs is not a new phenomenon and has reemerged with vigor. Decades ago, initiatives were formed to look at education reform, with a lens on the programs responsible for preparing teachers. One 
TEACHER EDUCATION REDESIGN: A COLLABORATIVE SELF-STUDY

of these, the Holmes Group, a consortium of deans and a number of chief academic officers from research institutions in each of the 50 states, was organized around the twin goals of the reform of teacher education and the reform of the teaching profession. Its landmark publication, Tomorrow's schools: Principles for the design of professional development schools (1990), led to strengthening both content and pedagogical knowledge for teacher candidates and also called for stronger relationships between universities and area schools with more connected field-based experiences (DarlingHammond, 2006; Darling-Hammond, Cheung, \& Frelow, 2002). Many current teacher education reforms owe some of their motivation to such efforts.

Unlike many high-performing schools in certain Asian and European countries, U.S. schools fail to consistently provide extensive opportunities for teacher candidates to spend significant time collaborating with teachers to develop lessons or discuss instructional strategies (Darling-Hammond, 2006). Research suggests that teacher candidates who have opportunities to engage in field-based, opportunities along with course work, are able to connect theory to practice and apply concepts they are learning in a more meaningful way than those without opportunities for quality field-based experiences (Ball \& Cohen, 1999; Baumgartner, Koerner, \& Rust, 2002; Boyd et al., 2008; Denton, 1982; Sampson, Linek, Raine, \& Szabo, 2013).

Numerous studies focus on the impact of teacher education programs on teacher candidates (Baumgartner, Koerner, \& Rust, 2002; Bullough \& Baugh, 2008; Capraro, Capraro, \& Helfeldt, 2010; Cochran-Smith, 2003; Conroy, Hulme \& Menter, 2013; Cuthrell, Stapleton, Bullock, Lys, Smith, \& Fogarty, 2014; Denton, 1982; Sterrett \& Bond, 2012). The goal of these studies is often to better understand the knowledge base 
TEACHER EDUCATION REDESIGN: A COLLABORATIVE SELF-STUDY

of the teacher candidate, as well as the overall achievement of students that work with the teacher candidates in local schools (Henry et al., 2013; Henry et al., 2014; Sterrett \& Bond, 2012). However, there is limited literature on the impact on teacher educators when redesigning a teacher education program. Albert et al. (1997) conducted a selfstudy to examine the impact of a new approach to teacher education on both pre-service teachers and faculty, but with a specific lens on social justice and their own biases and dispositions. Because teacher education programs continually grow and evolve based on backgrounds, dispositions, and institutional culture of both the teacher educators and teacher candidates (Hamilton \& Pinnegar, 2000), it is beneficial to consider the impact a redesigned teacher education program has on the teacher educators themselves, including how their dispositions and identities also evolve in the process.

\section{Self-Study}

While most self-studies related to teacher education focus on the experiences of teaching including but not limited to: individual practitioner and team teaching reflection, examination of specific teaching strategies and curricula, the roles of social identities (such as race, gender, class, sexuality), our study focuses on a gap within the current literature, mainly, the teacher educator identity shifts around redesigning teacher education programs (Teacher Urban Residency United, 2015). Over the last two decades, the use of self-study by teacher educators has become increasingly common and significant in the literature on teacher education (Zeichner, 2007). This type of research is critical in the field of teacher education, as what university faculty say, do, and model have a tremendous impact upon future educators. Teacher educators taking on a selfstudy inquiry become actively engaged in the research and reflection process, rather than 
TEACHER EDUCATION REDESIGN: A COLLABORATIVE SELF-STUDY

acting as passive evaluators, and seek to provide new insights on issues impacting education or teacher preparation (Garbett \& Ovens, 2012). Self-study serves as both a tool for developing and improving teacher education practices, and an avenue through which these practices may be shared with a larger community of teacher educators (Dinkelman, 2003). The benefits of collaborating in self-study, as opposed to individual reflection, include: the inclusion of a variety of perspectives to an area of concern or interest related to teacher education, the opportunity for collegial dialogue around teacher education practices, and the space it creates for community building (Louie et al., 2003). Our study hopes to build on such inquiry by examining our shifting collective and individual identities around TLLSC.

\section{Our Self-Study Methodology.}

We employed narrative self-study over a period of one year as the method to arrive at our findings. Because narratives are both the object of investigation and the actual method of investigation (Milner, 2008), we individually wrote reflections about ways in which the redesign process impacted our personal and professional identities, followed by regular group meetings to discuss the writing, remembering and sentient processes of self-study. As Elbaz-Luwisch (2001) noted, "we need to pay attention to our own stories as teachers [and teacher educators] if we are to be able to attend to the stories of pupils. This is the case at all levels of education” (p. 133). We knew we had to engage our own stories in order to make sense of the redesign process and its potential impact on our teacher candidates. Dinkelman (2003) notes that , "the simultaneous rise in interests in both reflective teaching and self-study is not coincidental. An argument can be made that there are close conceptual and practical ties between these two movements in teacher 
TEACHER EDUCATION REDESIGN: A COLLABORATIVE SELF-STUDY

education” (p. 8). By embarking on an intentional inquiry of our own redesign process, we sought to understand our practice more deeply; we also saw this as an opportunity to model self-reflection for our teacher candidates.

We began by putting a call out to our entire Teaching and Learning faculty (consisting of 21 members) at the end of the fall 2014 semester, inviting all those interested to engage in a discussion about how our program was impacting us, using selfstudy as a tool to get us there. We received responses from eight faculty members indicating interest in participating, six of whom remained active and are now authoring this piece. We met for the first time in early December 2014 where we created a timeline for the study. At this meeting, we discussed relevant articles that we agreed to read in advance of future meetings. Given that each of us had varying degrees of familiarity with this methodology, this activity served to establish a foundation of shared knowledge and vocabulary around self-study.

Data Analysis

We employed a narrative mode of analysis that attends to the particular characteristics of actions that take place in a specific setting; this analysis is about "the configuration of the data into a coherent whole” (Polkinghorne, 1995, p. 15) while maintaining the integrity and dynamism of a story. Polkinghorne (1995) notes, "Narrative reasoning operates by noticing the differences and diversity of people's behavior. It attends to the temporal context and complex interaction of the elements that make each situation remarkable” (p.

6). Because narrative research is "always interpretive at every stage” (Josselson, 2006, p. 4), we do not pretend to be in neutral, objective positions. Rather, we used our own subjectivities to inform our analyses, inviting one another's critiques and feedback 
TEACHER EDUCATION REDESIGN: A COLLABORATIVE SELF-STUDY

throughout the data analysis process. We began by coding the data, creating categories to group the codes, identified patterns and finally developed themes (Creswell, 1998) which are discussed in our findings section. We followed Louie et al.'s (2003) tenet, "In analyzing their data, self-study researchers must look for both frequent and rare events and remain open to disconfirming evidence” (p. 163).

\section{Program Context and Our Changing Organizational Identity}

Teaching Learning and Leading in School Communities (TLLSC) is a field-based teacher education model bringing together teacher educators, teachers, and candidates in classrooms, schools, and informal education settings (see Figure 2). In this redesigned program, TLLSC candidates spend approximately 80 percent of their time in schools, community organizations and cultural institutions. This means that they take traditional university-based coursework in concert with consistent field experiences. University instructors collaborate with classroom teachers as well as professional and community educators to support the learning of candidates in field-based experiences that includes both course-based discussion and field-based hands-on experiences with PK-12 students (Heineke, Ryan \& Tocci, 2015).

Groups within our Teaching and Learning (T\&L) faculty were no longer based on program area affiliation, but rather on the unique knowledge and perspective contributions individuals could bring to working groups. As part of the redesign process, working groups were formed and reformed as the program was developed and development required different types and levels of expertise (e.g. diverse disciplinary points of view, leadership styles, knowledge of schools/partnerships, experience with 
teacher education policies and practices, etc.). The purposeful grouping and re-grouping to do the redesign work allowed faculty to expand and shift as they now identified with TLLSC through their unique expertise and contributions. The continued work on TLLSC drew heavily on the practice of combining different faculty into smaller work groups to shape the design and development of the program. These smaller groups brought information back to the entire TLLSC faculty, discussed changes to the products and ensured the vision of preparing teachers to teach all students was present and represented by the entire group. As the program was implemented, faculty continued to interact and draw upon each other's individualized expertise to address problems and deliver instruction, including co-teaching of modules, or cross teaching of students within modules.

Our presentations of the redesign of our teacher preparation program to others also offers a window into how the program and our community of practice changed over time in working on TLLSC. In an early presentation (June, 2012) to other teacher educators involved in a grant project with us, we focused on a simple graphic of what traditional teacher preparation looked like and how we envisioned our model would differ. We laid out our central question: What do we need to do to prepare diverse candidates that will work with diverse learners in diverse settings having a positive impact on student learning and behavior outcomes? This was followed by a slide outlining key decisions in our process, actual steps taken in our process, and then the "enduring understandings" of the program. While this presentation was brief and represented a work in progress, by August 2012 we presented to the Illinois P-20 Council and our message reflected a stronger shift in identity. The triangle had the added title, 
"Challenging the Old Framework", but one of the final slides acknowledged "Challenges of the New Framework”. We already had a sense of where we were going and the potential obstacles that lay ahead - staffing, developing partnerships, and providing professional development for our faculty to be teaching across areas.

By spring of 2013, our presentation of TLLSC (May, 2013) included formal infographics with a logo for TLLSC and a chart with an image of the old triangle, but now the infographic included extensive text comparing traditional teacher preparation with what TLLSC offered over other models (see Table 1). In this presentation, there was a clear sense of identifying the program and the teacher educators who had designed it as fully committed to field-based teacher preparation. By August of 2013, and on the eve of implementation, the presentation included a list of school and community partners with a GIS map of partners' locations. The connection and importance of partners had always been an integral part of the narrative in previous presentations as embedded in the key decisions to include partners in the design phase of the program, but now there was a greater focus on partners in the presentation. This emphasis and our identification with partners continued to grow in subsequent presentations (May, 2014; October, 2014). In October of 2014, in a presentation to peers at the Council for the Accreditation of Educator Preparation, we highlighted our partnerships and focused on one of our founding principles of the TLLSC model, mutual benefit, grounded in the work of Kruger et al. (2009). In this presentation we forwarded our own ideas about developing a framework for establishing partnerships and maintaining those adding nuance to the differences between school and community partnerships. We also offered the notion that program redesign needed to be reconsidered as continuous program design. This 
TEACHER EDUCATION REDESIGN: A COLLABORATIVE SELF-STUDY

particular concept, perhaps more than others, offers a sense of how much engaging in the redesign of our program shifted our identity as teacher educators. Many of us understand our roles very differently now than we did some four years ago when we began this work. Even more so, many of us understand this work more as a continuing journey than an end point.

Once implementation of TLLSC was underway, we came to understand and identify who we were in this new context. The redesign of TLLSC prompted critical thinking and analysis of our internalized and enduring values and beliefs (Hogg \& Turner, 1987) as well as our roles, relationships and ways of acting, influenced by our interaction with each other and the larger community we were serving (Tajfel \& Turner, 1985). We believe that by evaluating our experiences during our changing program, we gained a new sense of purpose, further defining the TLLSC organizational identity, and in turn, our personal identities within TLLSC (Bridges, 2009). Engaging in this type of self-study can challenge teacher educators to consider discord between ideologies and practice, to explore complexities of their identities, and to collaborate with other faculty sharing their research interests (Louie, Drevdahl, Purdy, \& Stackman, 2003). In the next section, we describe our findings from our self-study, exploring our written reflections, as both the object of investigation and method (Milner, 2008).

\section{Self-Study Findings}

Our study’s major finding was that radically changing a teacher educator program from a traditional model to a genuinely field-based model indeed required an identity shift in teacher educators. Specifically, we found that the intentional examination of our individual internal conflicts regarding the role and identity of a teacher educator, our 
TEACHER EDUCATION REDESIGN: A COLLABORATIVE SELF-STUDY

skepticism and anxiety around making substantive change, and fear of being ill equipped to deal with the iterative nature of the program redesign may have all played critical roles in implementation; in other words, the evolution of our professional identities as educators directly corresponded to the evolution of the identity of the teacher education program. As the program changed, we, as teacher educators, also changed. Within this process, we discovered multi-directional, evolving tensions and unintended revelations about our own collective and individual identities, as well as a blending of our professional and personal identities.

Our individual identities as teacher educators interacted with (and were, in turn shaped by) TLLSC; this was simultaneously an intrapersonal experience and one of social and cultural co-construction with colleagues. Changes in professional roles during the redesign process at times resulted in challenges to our self-efficacy and questions regarding our value in the program. We each entered TLLSC at a unique point in its development/implementation. These diverse entry points (see Figure 1) corresponded to diverse types of identity shifts. We review below three central themes that emerged in our self-study around our shifting identity and how these changes uniquely impacted our identities as teacher educators and as individuals.

\section{Changing Roles: A Site for Doubt and a Catalyst for Teacher Educator Enthusiasm}

The first central theme emerging from our experiences was how the programmatic change altered our role as educators. Adam wrote about his own feelings of selfconfidence and how he faced the challenge of envisioning his changing role as a fieldbased instructor of early childhood special educators: 
TEACHER EDUCATION REDESIGN: A COLLABORATIVE SELF-STUDY

I am realizing that lack of vision was evidenced by a lack of confidence; I doubted my ability to mentor practicing novices, but it turns out that I am just as energized (and anxious) about addressing issues of practice as they now are.

Adam experienced a realization that while his role as a teacher educator shifted significantly, his enthusiasm about the program also grew, despite still having initial doubts about filling the role of a field-based mentor in this new program.

Sabina also recognized that field-based teacher education would require new roles; specifically, new types of collaboration and engagement with multiple nested systems. She described how this deep engagement raised questions regarding her identity:

For me, the question of what would I be doing, ran deeper and felt more aptly a question of who will I be and how will I be as a member of this community of practice, a community composed of nested, concentric circles—me teaching my teacher candidates, placed in classrooms with practicing teachers instructing their students, in schools growing and leading their practicing teachers to be part of the larger educational dialogue.

Ann Marie, as program director and leader of TLLSC, also saw ways that her professional role expanded dramatically, leading to growth and diversification of her leadership skills as she shifted contexts and collaborators, and evolved professionally along the way:

The days of developing the program were exhilarating and exhausting. I worked with my higher education colleagues, PK-12 colleagues, museum educators, community educators, and others. Days were filled with travelling to a series of 
TEACHER EDUCATION REDESIGN: A COLLABORATIVE SELF-STUDY

meetings and nights were filled with writing curriculum and reviewing others' work. The process pulled on every skill set I had and more. I know my identity as a leader was challenged and that I grew.

In each of these cases, we came to realize that the process and product of the effort challenged and shaped our identity as leaders and instructors. While all of us described tensions, that is, anxieties or obstacles to these changes, each of us also described ways in which meeting these challenges were meaningful or even "exhilarating.”

\section{Collaborative Identity in the Service of Collaborative Work}

As we each considered how our individual roles evolved as a result of our involvement with TLLSC, we also identified some of the ways in which our identities were linked to the program. As our individual identities evolved, we began to incorporate a new aspect of our identity - one that was collective in nature. This was a direct result of the emphasis on collaboration as the heart of TLLSC. Our identities were inevitably impacted by one another; we were linked with one another as we coconstructed layers to our identities. Ann Marie captured some of the ways in which her experience with TLLSC was shaped and driven by the process of facilitating several simultaneous forms of collaborative work, each with its own team members and goals:

I was pulled into a leadership role, but one that I strove to make collaborative. I worked with my colleagues to distribute the work and take on pieces of the work where each of us had expertise. Sometimes this was successful and in some cases less so. Overall, it worked. Faculty members from across our areas took up the 
TEACHER EDUCATION REDESIGN: A COLLABORATIVE SELF-STUDY

charge to contribute, design, develop, pilot and redesign. I worked to facilitate and at the same time dive into the work itself.

The process of collaborative co-creation extends into faculty's experiences of implementation and iterative redesign. Aurora wrote, “...In many ways, all of our identities are shaping the redesign's identity since we are all so intimately involved in its shaping and evolution.” Some of us may have been aware from the start that this would occur, but for others, this was a revelation. The teacher preparation program that we all created had an identity of its own — one that is inevitably impacted by how we saw ourselves as teachers, as teacher educators, as advocates for PK-12 students, as collaborators with PK-12 classroom teachers, and as activists who strongly believe in education for social justice. However, it could never be a one-way street. Our existing layers of identity, the complex names we gave ourselves, would continue to shape the way the TLLSC program grew and changed over time, regardless of our entry point into the process.

\section{Actualizing Personal Goals through Program Development}

Whether we came into the program with concerns about our own adequacy, with strong convictions that we could (and should) be doing this type of teaching, or even if we questioned aspects of the program itself, it was clear in the data that we all emerged with renewed enthusiasm, growing confidence about our professional abilities, and faith that what we were doing was the best approach to teacher education in our urban environment. None of us were “outsiders” anymore---we all realized the tremendous role we played in the life of the new program. We became not just insiders, but advocates, for the program. David wrote: 
TEACHER EDUCATION REDESIGN: A COLLABORATIVE SELF-STUDY

I really believe that good learning occurs best in authentic situations or natural situations. This is not only my professional view of what good learning is but it's also my personal view of it. If I think back over my life the learning that I enjoyed the most was closely linked to the actual activities that the learning was associated with and I think our program typifies that by placing students out in real life context as we're preparing them to be future teachers.

Literature on group identity often emphasizes the ways in which group values and purposes eclipse self-driven values and purposes. That is, "the attributes and behaviors of the individual self are assimilated to the representation of the group as a whole, enhancing those features that make the group distinctive” (Brewer \& Hewstone, 2003, p. 145). Yet, an unintended consequence of this group endeavor, to redesign our teacher education program, is that in many ways, it allowed our individual purposes, and values about education, which had been dormant in other contexts, to be revealed and strengthened. Ann Marie’s description of how the program “pulled on my administrative skill sets. I was pulled into a leadership role, but one that I strove to make collaborative.” She contrasts this new role with her previous experiences in the academy where "my preferred work in research and writing is actually more solitary (I am a historian). I now find myself in a different space for this phase of my career.”

The redesign's ability to rouse dormant characteristics of individual members is evident in Aurora's writings. Aurora explains that "the redesign identity is an activist identity" and she emphasizes that she "has always embraced a spirit of resistance to isms, practicality over theory and working from the bottom up.” In our meetings, Aurora would contrast this stance to other academic environments and approaches where activism was 
TEACHER EDUCATION REDESIGN: A COLLABORATIVE SELF-STUDY

far from the core of the program and thus tempered her ability to manifest her activism. David echoed these same sentiments, that the redesign allowed him to actualize values he espoused in a more active way, he highlights that:

being involved in the redesign really spoke to the personal parts of me.... as I look back over my careers developing and building new programs has always been a key part of what I've done for organizations and so the redesign was as an opportunity to bring those skills that I really enjoy into practice again.

David's comment demonstrates how the redesign provided an opportunity to employ skills which had not been put to use in other academic spaces, and that enacting these while contributing to a developing group identity also furthered his personal values and purposes around education related issues. The same may be said for Aurora as an activist and Ann Marie, as a leader and organizer. This idea is clear in Sabina's discussion of her previous work in educational settings, she explains that:

having been an interventionist in schools all over Boston, in Buenos Aires, Argentina and Calca, Peru--where I also moved between classrooms providing supplementary support-- this model resonated with my commitment to solving real problems of practice and responding to local needs.

\section{Academic Identity versus Teacher Educator Identity}

The need and opportunity to capitalize on skills and passions held by individual faculty members also revealed a tension embedded in our changing approach: it deviated from traditional understandings of the life of an academic. Across faculty members, despite the power of TLLSC to revive skills that each member personally valued and felt happy to 
TEACHER EDUCATION REDESIGN: A COLLABORATIVE SELF-STUDY

embrace, the discussions around these skills showed that we were all torn about the implications of the changing landscape of teacher education for academic ways of being. More specifically, many faculty members expressed a sense that these values and purposes might be in conflict with general approaches to work in the academy and success in the ivory tower.

Indeed, in Ann Marie's writing, she contrasts her new collaborative role with her work as a historian—one who works alone and toils alone on his/her academic endeavors. Sabina draws a similar distinction between the redesign and conceptions of what it means to be an academic, she writes that:

finishing graduate school and my postdoctoral fellowship, the lessons learned for being professionally successful in academia were: do what you know best, collaborate with colleagues who share your theoretical lens, narrow your focus, and lead. These would be mantras I would have to question.

Aurora expresses her concern about working with others:

The idea of collaborating with other faculty on the curriculum of the program seemed uncomfortable. I will admit that part of the reason that I like faculty life is that it is so autonomous - would this increased collaboration take away from that sense of autonomy?

Aurora's concern is rooted in an understanding of what is valued in the academy more broadly, routines that have been ingrained in our sense of what we do and how we do it. This tension is what made the redesign daring and difficult, as it involved relinquishing messages propagated by the academy, and "denounc[ing]" individual success for the greater educational good. Sabina elaborates on this tension, but also how going against 
TEACHER EDUCATION REDESIGN: A COLLABORATIVE SELF-STUDY

traditional academic approaches created a sense of pride for those participating in the redesign:

In these practices, I have learned that I am enacting exactly what training in education should be, the ability to adapt and collaborate in complex dynamic learning spaces, and to apply a pedagogical wisdom grounded in the messy, that undercuts all our decisions: be responsive, be authentic, make the world a better place not just a more orderly one.

These themes address our changing roles as spaces for doubt and simultaneously catalysts for greater enthusiasms for our field. Further, these findings demonstrate the ways in which the collaborative nature of this work made a collaborative program identity possible and rewarding, and that we were able to actualize personal goals through this model, acknowledging, at the same time, that these other goals and values were in contrast to some of the more typical practices characteristics of the academy. More broadly, these themes reveal how tensions, that are a necessary part of change, were also powerful in increasing our enthusiasm for the program and our understanding of what a field-based program model entails.

\section{Discussion and Implications}

What we learned from the study

In this section, we take each of our findings' themes and discuss their implications. Our self-study revealed that TLLSC created a context for doubt and a catalyst for teacher educator enthusiasm. The ongoing and dynamic development of TLLSC continues to challenge us, changing our roles and allowing our collective and individual identities to evolve iteratively. Our data shows that the more synergistic the alignment between 
individual and collective identity, the more buy-in and dedication that results. Our findings indicate that responsiveness to all stakeholders in TLLSC allows everyone to leverage unique talents and abilities while maintaining and strengthening their identities. Much like individual teachers in their classrooms, we actualized our personal goals through our program development by going about the work of educating in our own way within a framework of serving all children and within the confines and pressures of educational policy and the role as a professor (Knowles \& Cole, 1994). The bottom line is we want to serve children and families as well as the field of teacher education, and this means that we have to build genuine alliances with communities, commit ourselves to being our best selves while also leaving room for flexibility as our organizational and individual identities evolve.

A central theme that emerged in our experiences of our shifting program model was how such a change in approach shaped our identities as educators while "identifying and respecting the various ingredients of professional identity” (Coldron \& Smith, 1999, p. 711). While this role change was unsettling, it was also exhilarating. Indeed, our own critiques of our teaching practices opened the door to change and left us feeling empowered. However, our identities as teacher educators are not static (Coldron \& Smith, 1999). We are only in the beginning stages of this work; the future can only tell how we will feel a year out, two years out, and beyond. The conception of self, as we learned, is complex, multidimensional and dynamic - shaped by forces that our sometimes out of our control. As Coldron and Smith contend (1999), “an individual teacher's professional identity/location is, on the one hand, determined biographically, through his or her own choices and, on the other, socially 'given’” (p. 714). 
TEACHER EDUCATION REDESIGN: A COLLABORATIVE SELF-STUDY

With respect to the collaborative identity in the service of collaborative work, who we are as teacher educators, both individually as professionals and collaboratively as a teacher education program, depends upon the people involved, the current sociopolitical circumstances, and the overarching demands placed upon us on national, state and university levels. Indeed, "those who engage in self-study often confront an apparent contradiction, for self-study is not the private and personal affair that the label might suggest. Self-study relies on interaction with close colleagues who can listen actively and constructively” (Russell, 2006, p. 5). We hope to institute self-study as a continued practice in our teacher education program as a vehicle for reflexivity and continued improvement. In the immediate future, we hope to carve out a space in our departmental meetings to be able to discuss how our identities evolve as the program’s identity evolves. As we aim to connect our theoretical understandings of sound pedagogical practices within an iterative teacher redesign program to meaningful practice, our teacher educator identities will continue to shift. We agree with Loughran (2007) that “an important aspect of self-study that is crucial in understanding this method is embedded in the desire of teacher educators to better align their teaching intents with their teaching actions” (p. 12). Indeed, this would be a sign of health and in keeping with our original intent.

Taking teacher candidates and teacher educators out into the field rather than confining them to the walls of the ivory tower is a bold move and one that is worthwhile. For those teacher education programs in the midst of slight change or overall redesign, it is critical to acknowledge the political nature of this work, not to shy away from difficult conversations, and to be explicit about the political landmine that is 
TEACHER EDUCATION REDESIGN: A COLLABORATIVE SELF-STUDY

teacher education. Redesigning a teacher education program is not for the faint of heart and requires a fierce honesty and unyielding support. Anyone undertaking this endeavor should enter into it with eyes wide open with the understanding that a redesign process not only impacts the overall teacher education program identity but the personal and professional identities of the teacher educators within it.

Embedded in this transformation of our work is moving the academic/scholar outside of the privacy of his/her office and university classrooms to the public sphere of real world schools and the people within them. With the transformation of the way we do business in teacher education emerges a change in the ways we do academia. This is no small feat nor does it come without criticism or resistance both from inside and outside of our communities. We step into a space rife with already existing conflict, that is, the world of teacher education; we ask different questions, engage with our community partners and strive to nurture and develop our identities so that they align with social justice values.

\section{Limitations of the Self Study}

Several limitations to this study warrant mention. First, because we are all insiders within this program, the stakes for its success are high. In this way, our discussions and analyses of our data leaned in a positive direction, because all of us were invested in the program's success for personal and professional reasons. In essence, our livelihoods and our contentment with our jobs, depend on its effective implementation. Our positive lens for examining our experiences, was in many ways necessary for us to support our roles as efficacious teacher educators and the sustainability of the program overall. It is possible that had this work been conducted by those for whom the personal stakes were lower that 
TEACHER EDUCATION REDESIGN: A COLLABORATIVE SELF-STUDY

the findings might have differed. However, we would argue that to do this work requires personal and professional investment and that program shifts are generally led by internal faculty stakeholders. Thus, the present inquiry reflects the realities of teacher educators in many schools around the country.

Secondly, we are writing this manuscript at a time when we do not have substantive data on the effects on our students. While we have emerging data (Heineke, Ryan, \& Tocci, 2015; Kennedy \& Lees, 2015) and anecdotal accounts of the TLLSC’s positive impact on our students, faculty and community partners, the potential long-term effects of this programmatic change are still unknown. As such, our positive attitudes about the program and our changing identities reflect our commitment to the program model that is theoretically and empirically grounded. However, the enthusiasm described might change in the face of less positive student outcomes.

Finally, this paper was in development during program construction and identity construction. As we well know from existing literature, identity changes over time; therefore, it is quite likely that a year from now, we could interpret this iterative design process differently. We are bound by the particular time and space in which we find ourselves.

\section{Future Directions and Hopes}

Dinkelman (2003) notes that, “when teacher educators adopt self-study as an integral part of their own professional practice, the terrain of teacher preparation shifts. Self-study becomes more than just a means to the treasured aim of reflective teaching — self-study becomes an end of teacher education in its own right” (p. 6). Our data raise several implications for the field more broadly and for how teacher education programs can and 
should evolve within the present educational landscape. The cultural, intellectual, and political dimensions of the professorate compelled us to engage in self-study to establish our identities and values within the academic community (Louie et al., 2003). In thinking about future directions for this work, we have found it beneficial to think about what we would have liked to have more of during the time in which this process began. We concur with Bullough \& Pinnegar's (2001) assertion that self-study research aims "to provoke, challenge, and illuminate rather than confirm and settle" (p. 20). Our self-study raises more questions than answers. In that vein, we would have benefitted from more time for reflection. We had the foresight to plan a self-study along with the redesign, but it proved challenging to do given our obligations to both deliver our current program at the time, while we envisioned and designed a radically new one. The engagement in this self-study has reaffirmed the benefits of taking the time to reflect on both the process and our own professional growth. We suggest to those planning such a redesign effort to embed the time for reflection in the process upfront and to hold firm on keeping it as part of the process.

Lastly, we invited and were fortunate to have faculty, staff, local PK-12 teachers, administrators and community members as a part of our redesign teams. This also included alumni and graduate students in our curriculum and instruction program. The one group that we failed to significantly engage was that of undergraduate and graduate initial teacher preparation students. These students now provide a valuable perspective on the program; however, by including their voices from the beginning, we would have incorporated their experiences and input earlier in the process, rather than relying on the data from the program to virtually represent them. 
We hope that other programs engaging in this kind of change will use self-study as a means of documenting the personal and professional shifts necessary to do this work. We see this reflective work as central to improving the implementation of these new programs, as such extensive institutional changes force faculty to make meaning of their professional identities in unexpected, complex and dynamic ways. Our professional identity shift co-occurred with our changing programmatic model and shaped who we are as individual faculty and a community of practice. We realized that shifting the identity of a teacher education program and the teacher educators within it requires hard work—it also requires courage. 
TEACHER EDUCATION REDESIGN: A COLLABORATIVE SELF-STUDY

\section{References}

Albert, L. R., Cochran-Smith, M., DiMattia, P., Freedman, S., Jackson, R., Mooney, J., Neisler, O., Peck, A., \& Zollers, N. P. (1997, March). Seeking social justice: A teacher education faculty's self study, Year I. Paper presented at the Annual Meeting of the American Educational Research Association, Chicago, IL.

Ashforth, B. E., \& Mael, F. (1989). Social identity theory and the organization. The Academy of Management Review, 14(1), 20-39.

Ball, D. L., \& Forzani, F. M. (2009). The work of teaching and the challenge for teacher education. Journal of Teacher Education, 60(5), 497-511.

Baumgartner, F., Koerner, M., \& Rust, F. (2002). Exploring roles in student teaching placements. Teacher Education Quarterly, 29, 35-58.

Bullough, R.V. (2014). Toward reconstructing the narrative of teacher education: A rhetorical analysis of preparing teachers. Journal of Teacher Education, 65(3), 185-194.

Bullough, Jr., R. V., \& Pinnegar, S. (2001). Guidelines for quality in autobiographical forms of self-study research. Educational Researcher, 30(3), 13-21.

Boyd, D., Grossman, P., Lankford, H., Loeb, S., \& Wyckoff, J. (2008). Teacher preparation and student achievement. Washington, DC: Urban Institute, Center for Analysis of Longitudinal Data in Educational Research Working Paper, 20.

Brewer, M.B., \& Hewstone, H. (2003). Self and Social Identity. San Francisco, CA: Blackwell.

Bridges, W. (2009). Managing Transitions $3^{\text {rd }}$ ed. Philadelphia, PA: Da Capo Press. 
TEACHER EDUCATION REDESIGN: A COLLABORATIVE SELF-STUDY

Bullough, R.V.. \& Baugh, S.C. (2008) Building Professional Learning Communities Within a University_Public School Partnership, Theory Into Practice, 47:4, 286293.

Capraro, M.M., Capraro, R.M., \& Helfeldt, J. (2010). Do differing types of field experiences make differences in teacher candidates’ perceived level of competence? Teacher Education Quarterly, 131-154.

Cochran-Smith, M.. (2003). The Multiple Meanings of Multicultural Teacher Education: A Conceptual Framework. Teacher Education Quarterly, 30(2), 7-26. Retrieved from http://www.jstor.org/stable/23478466

Cochran-Smith, M., \& Lytle, S. L.. (1999). The Teacher Research Movement: A Decade Later. Educational Researcher, 28(7), 15-25. Retrieved from http://www.jstor.org/stable/1176137

Coldron, J., \& Smith, R. (1999). Active location in teachers' construction of their professional identities. Journal of Curriculum Studies, 31(6), 711e726.

Conroy, J., Hulme, M., \& Menter, I. (2013). Developing a “clinical” model for teacher education. Journal of Education for Teaching, 39(5), 557-573.

Creswell, J. W. (1998). Qualitative inquiry and research design: Choosing among five traditions. Thousand Oaks, CA: Sage.

Cuthrell, K., Stapleton, J.N., Bullock, A.A., Lys, D.B., Smith, J.J., \& Fogart, E. (2014). Mapping the journey of reform and assessment for an elementary education teacher preparation program. Journal of Curriculum \& Instruction, 8(1), 67-85. Darling-Hammond, L. (2010). Teacher education and the American future. Journal of Teacher Education, 61, 35-47. 
TEACHER EDUCATION REDESIGN: A COLLABORATIVE SELF-STUDY

Darling-Hammond, L. (2006). Constructing 21 ${ }^{\text {st }}$-Century Teacher Education. Journal of Teacher Education, 57 (3), 300-314.

Darling-Hammond, L., Cheung, R., \& Frelow, F. (2002). Variation in teacher preparation: How well do different pathways prepare teachers to teach? Journal of Teacher Education, 53(4), 286-302.

Denton, J. J. (1982). Early field experience influence on performance in subsequent coursework. Journal of Teacher Education, 33(2), 19-23.

Dinkelman, T. (2003). Self-study in teacher education: A means and ends tool for promoting reflective teaching. Journal of Teacher Education, 54, 1, 6-18.

Elba-Luwisch, F. (2001). Understanding what goes on in the heart and the mind: Learning about diversity and co-existence through storytelling. Teaching and Teacher Education, 17(2), 133-146.

Forzani, F.M. (2014). Understanding “core practices” and "practice-based” teacher education: Learning from the past. Journal of Teacher Education, 65(4), 357-368.

Freire, P. (1998). Pedagogy of Freedom: Ethics, Democracy, and Civic Courage. Lanham, Maryland: Rowman and Littlefield.

Garbett, D. \& Ovens, A. (2012) Being a teacher educator: Exploring issues of authenticity and safety through self-study. Australian Journal of Teacher Education, 37(3), 44-56.

García, E., Arias, B. M., Harris-Murri, N. J., \& Serna, C. (2010). Developing responsive teachers: A challenge for a demographic reality. Journal of Teacher Education, $61,132-142$. 
TEACHER EDUCATION REDESIGN: A COLLABORATIVE SELF-STUDY

Glazerman, S., \& Jeffrey, M. (2011). Do low-income students have equal access to the highest-performing teachers? NCEE Evaluation Brief (Document No. -11-23a). Washington, DC: U.S. Department of Education, Institute of Education Sciences, National Center for Education Evaluation and Regional Assistance.

Heineke, A.J., Ryan, A.M. \& Tocci, C. (In Press). Teaching, learning, and leading: Preparing teachers as educational policy actors. Journal of Teacher Education.

Hogg, M. A., \& Turner, J. C. (1987). Social identity and conformity: A theory of referent informational influence. In W. Doise \& S. Moscovici (Eds.), Current issues in European social psychology. (Vol. 2, pp. 139-182). Cambridge, England: Cambridge University Press.

Institute of Education Sciences (2014). Back to school statistics. Fast facts. Available at http://nces.ed.gov/fastfacts/display.asp?id=372.

Hamilton, M.L. \& Pinnegar, S. (2000). On the threshold of a new century: trustworthiness, integrity, and self-study in teacher education. Journal of Teacher Education, 51(3), 234-240.

Heineke, A., Ryan, A.M., and Tocci, C. (2015). Teaching, Learning, and Leading: Preparing Teachers as Educational Policy Actors. Journal of Teacher Education, 66, no. 4 (September/October 2015) 382-394.

Henry, G. T., Campbell, S. L., Thompson, C. L., Patriarca, L. A., Luterbach, K .J., Lys, D. B., \& Covington, V. M. (2013). The predictive validity of measures of teacher candidate programs and performance: Toward an evidence-based approach to teacher preparation. Journal of Teacher Education, 64, 439-453. 
TEACHER EDUCATION REDESIGN: A COLLABORATIVE SELF-STUDY

Henry, G. T., Purtell, K. M., Bastian, K. C., Fortner, C. K., Thompson, C. L., Campbell, S. L., \& Patterson, K. M. (2014). The effects of teacher entry portals on student achievement. Journal of Teacher Education, 65, 7-23.

Hökkä, P. \& Eteläpelto. (2014). Seeking New Perspectives on the Development of Teacher Education: A Study of the Finnish Context. Journal of teacher education, 65(1), 39-52.

Holmes Group. 1990. Tomorrow's schools: Principles for the design of professional development schools, A report of The Holmes Group. East Lansing, Ml: Holmes Group

Hong, J. Y. (2010). Pre-service and beginning teachers' professional identity and its relation to dropping out of the profession. Teaching and Teacher Education, 26(8), 1530e1543.

Kelchtermans, G., and Vandenberghe, R. (1994). Teachers’ professional development: a biographical perspective. Journal of Curriculum Studies, 26, 45-62.

Kennedy, A., \& Lees, A. (2015): Preparing undergraduate pre-service teachers through direct and video-based performance feedback and tiered supports in Early Head Start. Early Childhood Education Journal (June 2015). DOI 10.1007/s10643-015$0725-2$

Knowles, J. G., \& Cole, A. L. (1994). We're just like the beginning teachers we study: Letters and reflections on our first year as beginning professors. Curriculum Inquiry, 24(1), 27-52.

Kruger, T., Davies, A., Eckersley, B., Newell, F., \& Cherednichenko, B. (2009). Effective and sustainable university-school partnerships: Beyond determined 
TEACHER EDUCATION REDESIGN: A COLLABORATIVE SELF-STUDY

efforts by inspired individuals. Canberra, Australia: Teaching Australia Australian Institute for Teaching and School Leadership Limited.

Labaree, D. (2010). Teach for America and teacher ed: Heads they win, tails we lose. Journal of Teacher Education, 61, 48-55

Lortie, D.C. (1975). Schoolteacher. The University of Chicago Press: Chicago, IL. Loughran, J. (2007). Researching teacher education practices: Responding to the challenges, demands, and expectations of self-study. Journal of Teacher Education, 58, 1, 12-20.

Louie, B.Y., Drevdahl, D.J., Purdy, J.M., \& Stackman, R.W. ( 2003). Advancing the scholarship of teaching through collaborative self-study. The Journal of Higher Education, 74 (2), 150-171.

MacLure, M. (1993). Arguing for yourself: identity as an organising principle in teachers' jobs and lives. British Educational Research Journal, 19(4), 311e322.

McDonald, M., Kazemi, E., \& Kavanagh, S. (2013). Core practices and pedagogies of teacher education: a call for a common language and collective activity. Journal of Teacher Education, 20, 10, 1-9.

Milner, H. R., IV. (2008). Disrupting Deficit Notions of Difference: Counter-Narratives of Teachers and Community in Urban Education. Teaching and Teacher Education: An International Journal of Research and Studies, 24(6), 1573-1598. Murray, J. (2008). Toward the re-articulation of the work of teacher educators in higher education institutions in England. European Journal of Teacher Education, 31(1), $17-34$. 
TEACHER EDUCATION REDESIGN: A COLLABORATIVE SELF-STUDY

National Research Council (2010. Preparing teachers: Building evidence for sound policy. Report by the Committee on the study of teacher preparation programs in the United States. Washington, Dc: National Academic Press.

Polkinghorne, Donald E. (1995). Narrative configuration in qualitative analysis. Qualitative studies in education, Vol. 8, issue 2.

Rogoff, B. (1995). Observing sociocultural activity on three planes: Participatory appropriation, guided participation, and apprenticeship. In P. M. J. Goodnow \& F. Kessel (Eds.), Sociocultural studies of mind (pp.139-164). Cambridge: Cambridge University Press.

Russell, T. (2006). How 20 years of self-study changed my teaching. In C. Kosnik, C. Beck, A. R. Freese, \& A. P. Samaras (Eds.), Making a difference in teacher education through self-study: Studies of personal, professional and program renewal (pp. 3-18). Dordrecht, The Netherlands: Springer.

Ryan, Ann Marie, David Ensminger, Amy J. Heineke, Adam Kennedy, S. Kennedy, David P. Prasse, and Lara K. Smetana. Teaching, Learning, and Leading with Schools and Communities: One Urban University Re-Envisions Teacher Preparation for the Next Generation. Issues in Teacher Education 22, no. 2 (Fall 2014) 139-53.

Samaras, A.P. \& Freese, A. R. (2009). “Looking back and looking forward: An historical overview of the self-study school.” In C. A. Lassonde, S. Galman \& C. Kosnik (Eds). Self-Study research methodologies for teacher educators, (pp.3-19). Rotterdam: Sense Publishers. 
TEACHER EDUCATION REDESIGN: A COLLABORATIVE SELF-STUDY

Sampson, M.B., Linek, W.M. Raine, I.L., \& Szabo, S. (2013). The influence of prior knowledge, university coursework, and field experiences on primary preservice teachers' use of reading comprehension strategies in a year-long, field-based teacher education program. Literacy Research and Instruction, 52(4), 281-311.

Simon, N. S., \& Johnson, S. M. (2015). Teacher turnover in high-poverty schools: what we know and can do. Teachers College Record, 117, 1e36.

Sterrett, W. \& Bond, N. (2012). Beyond tough choices: Prioritizing and preserving education in times of cuts and layoffs. Kappa Delta Pi Record, 48(2), 52-54.

Tajfel, H., \& Turner, J. C. (1985). The social identity theory of intergroup behavior. In S. Worchel \& W. G. Austin (Eds.), The psychology of intergroup relations (Vol 2, pp. 7-24). Chicago, IL: Nelson Hall.

Teach Plus. (2015). Teach plus teacher preparation flash poll summary. Available at http://www.teachplus.org/sites/default/files/downloads/Documents/flash_poll_one _pager_with_graphics_udpate_jennie.pdf.

Teacher Urban Residency United (2015). Clinically oriented teacher preparation: What do we know about effective practices? An Urban Teacher Residency United Report.

Weiner, J., \& Torres, A.C (2016). Different location or different map? Investigating charter school teachers’ professional identities. Teaching and Teacher Education, $53,75-86$.

Zeichner, K. (2007). Accumulating knowledge across self-studies in teacher education. Journal of Teacher Education, 58, 36-46. 
Table 1. LUC TLLSC Comparison Table

Comparison of Program Elements of Traditional Teacher Preparation and Teaching, Learning, and Leading with Schools and Communities

\begin{tabular}{|c|c|c|}
\hline $\begin{array}{l}\text { Traditional Teacher } \\
\text { Preparation }\end{array}$ & Program Elements & $\begin{array}{l}\text { Teaching, Learning, and } \\
\text { Leading } \\
\text { with Schools and } \\
\text { Communities }\end{array}$ \\
\hline
\end{tabular}

University courses are followed by fragmented clinical experience.

A static model compartmentalizes coursework and clinical experiences.

Separating the roles of teacher and researcher reinforces the researchpractice gap and school-university divide.

Clinical super visors form a link between university-based faculty and cooperating teachers.

Teachers host candidates and follow university guidelines.

Faculty teach university-based courses.

Candidates accumulate knowledge in courses for later application in clinical settings.

Teacher preparation is successful when graduates pass certification examinations and are retained in professional settings.
APPROACH

FRAMEWORK

RESEARCH TO

PRACTICE

STAKEHOLDERS

PARTNERS

FACULTY ROLES

TEACHER CANDIDATES

DEFINITION OF SUCCESS
Faculty and candidates are embedded in schools and communities and develop through growth-based apprenticeship.

A reflexive model aimed at responsiveness to the needs of diverse children and families better reflects the complexity of teaching.

Practice is informed by and contributes to collaborative, fieldbased research.

University faculty form relationships with schools and community agencies to facilitate onsite work within neighborhoods.

Partners join professional learning communities and collaborate in preparation of future teachers.

Faculty mentor candidates, facilitate clinical work, and coordinate professional learning communities.

Candidates develop through guided reflective practice as professional educators and as leaders.

Graduates enter the field with greater professional resiliency, having already made an impact on children, families, schools, and communities. 
Figure 1. Years of entry for authors as they participated in the re-design process

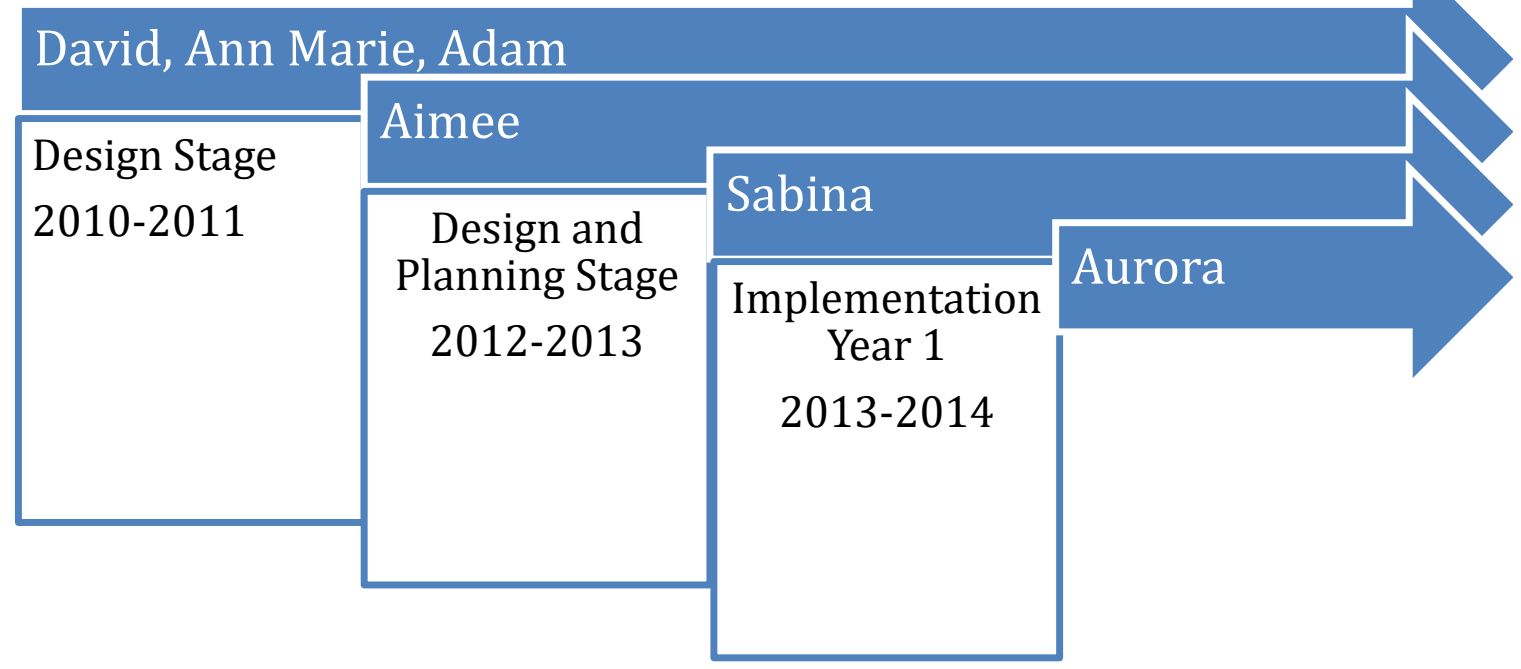

Figure 2. Loyola University BSEd Program Phases Infographic

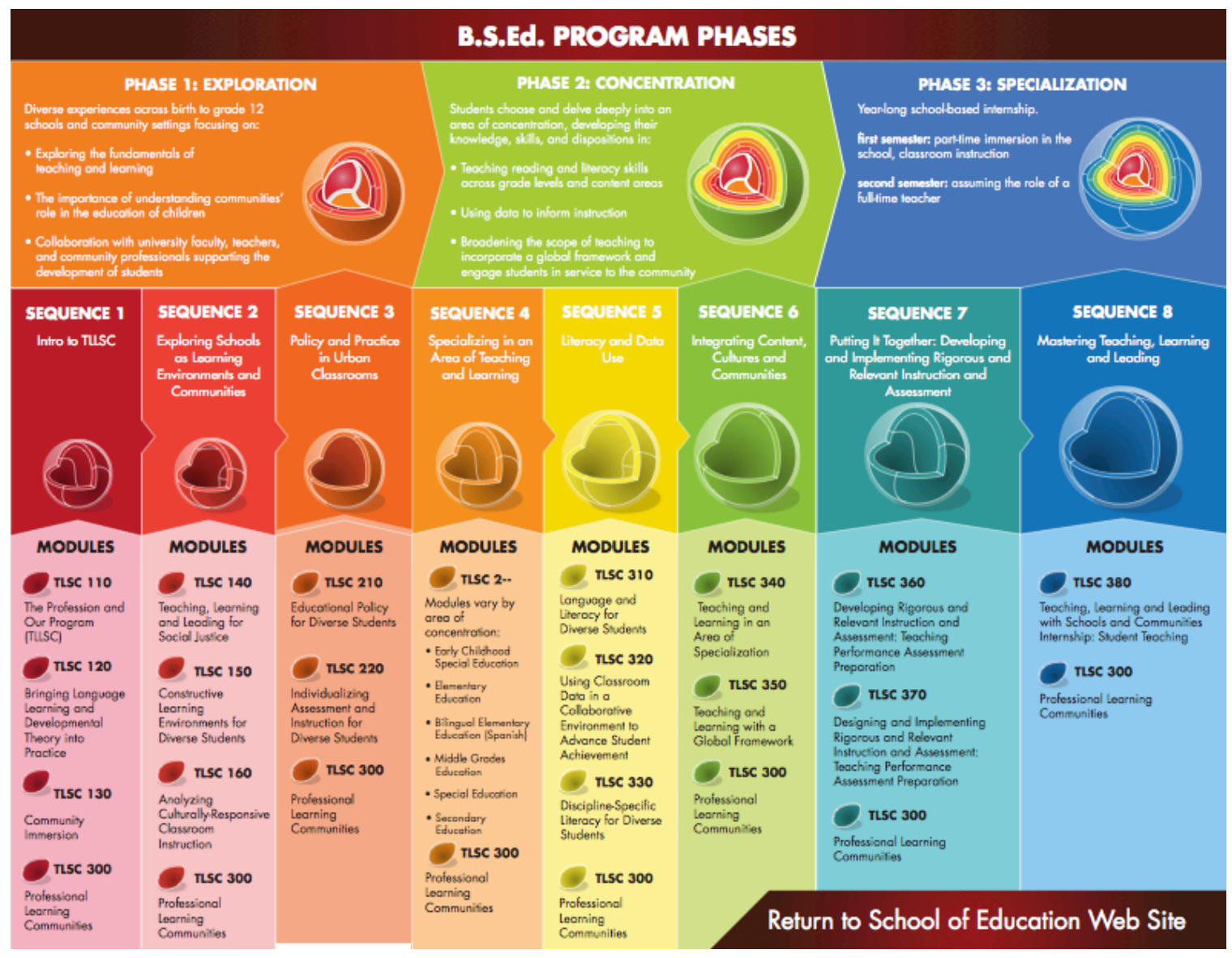

